\title{
A family study of vesicoureteric reflux
}

\author{
AidA DE VARGAS, KATHLEEN EVANS, P. RANSLEY, A. R. ROSENBERG, \\ D. ROTHWELL, T. SHERWOOD, D. I. WILLIAMS, T. M. BARRATT, AND \\ C. O. CARTER
}

From the MRC Clinical Genetics Unit and Department of Immunology, Institute of Child Health; Department of Urology, The Hospital for Sick Children; Department of Urology and Radiology, Institute of Urology, London

SUMMARY Vesicoureteric reflux is now considered to be due essentially to congenital malformation of the vesicoureteric junction. It is also considered to be a major cause of renal failure in early adult life. The condition is associated with recurrent urinary tract infection and in some instances with renal scarring. When reflux is detected clinically, in the investigation of patients with recurrent urinary tract infection, renal scarring is often already present. The reflux tends to disappear in later childhood.

A family study has been made based on 186 index patients with established primary reflux, with special attention to a history of genitourinary symptoms in the sibs and parents of these patients. There were 39 sibs under the age of 4 years. For these the parents were offered investigation by micturating cystogram. The parents of 20 accepted. Reflux was shown in 3, and in 2 of these there was already renal scarring. The proportion of all infants and young children who have reflux is not accurately known, but the few published surveys of screening of normal infants and young children by micturating cystogram suggest that the prevalence is of the order of $1 \%$. The prevalence in sibs is, then, about 10 times higher. There was a main group of 214 sibs over the age of 4 years. For these the parents were offered investigation by intravenous pyelogram only for those sibs who had a history of recurrent urinary tract infection. If renal scarring was found then a micturating cystogram was done. Of 110 sisters, 12 were 'symptomatic', renal scarring was found in 5 of these ( 1 was on haemodialysis), and reflux was still present in 3 . Of 104 brothers 7 were 'symptomatic', renal scarring was found in 2 and reflux was present in both. For comparison, the published reports of several surveys of schoolgirls indicate that about 2 in 100 have recurrent urinary tract infection, and in about a quarter of these $(0.5 \%)$ reflux was present and in about one-eighth $(0.25 \%)$ renal scarring was present. The prevalence in sibs is, then, 10 to 20 times higher. Similarly in the parents: of 183 mothers 7 ( 1 was on haemodialysis) and of 181 fathers 2 had renal scarring.

The family findings are consistent with multifactorial inheritance, as with other common malformations.

Routine investigation, in infancy, of younger sibs of patients with vesicoureteric reflux would identify patients in whom the reflux was recognised very early. These would be valuable for the study of the natural history and management of the disorder, and the degree to which it was possible to prevent the development of renal scarring.

Vesicoureteric reflux (VUR) with its related nephropathy is a major cause of renal failure in early adult life (Hodson and Edwards, 1960; Scott and Stansfeld, 1968; Smellie and Normand, 1968; Bailey, 1973). The anomaly which underlies VUR is probably congenital, consisting of an inadequate development of muscle at the ureterovesical junction, a shortening of the intravesical segment of the ureter, and widening of the Received for publication 21 September 1977 ureteric opening into the bladder (Stephens and Lenaghan, 1962; Tanagho et al., 1969). This permits reflux of urine from the bladder up the ureters to the kidneys in infancy and early childhood. However, VUR tends to disappear and in most patients has ceased by the early teens (Smellie et al., 1975).

Many single families have been reported with more than one member affected by VUR (Lewy and Belman, 1975). Several surveys have indicated an 
increased prevalence of VUR among close relatives of patients with the condition (Baker et al., 1965; Mulcahy et al., 1970; Burger and Smith, 1971; Amar, 1972; Bois et al., 1975; Atwell et al., 1977). Dwoskin (1976) studied the sibs of 125 patients with VUR and found that 54 of their 204 sibs also had VUR. This series was selected as only the families where parents permitted micturating cystograms on their children were included. Such studies, nevertheless, suggest that relatives of patients might provide a high risk group where routine screening might be appropriate. However, none of the surveys reported hitherto provides an accurate estimate of the proportion affected of sibs of index patients with VUR. The present study was planned to provide such an estimate.

The tendency of VUR to disappear in later childhood presents certain problems in the determination of the prevalence of the disorder in relatives. Micturating cystogram (MCU) will underestimate the frequency of the disorder in the older children and adults. The demonstration of renal scarring on intravenous urography (IVU) suggests the previous existence of VUR, though scarring is only found in 30 to $60 \%$ of children with VUR (Smellie et al., 1975; Scott, 1977), and it may be difficult to distinguish radiologically between features of renal dysplasia and the scarring of reflux nephropathy.

As a compromise, therefore, in this study we elected to screen, wherever parents gave informed consent, the sibs of index patients in the following way: where the sibs were under the age of 4 years screening was by MCU for VUR followed by IVU if reflux was found to be present; where they were older by IVU for renal scarring if there was a history of urinary tract infection (UTI), followed by MCU if scarring was found. It was, however, also decided at the start of the study to offer the parents of the first 29 index patients routine IVU for renal scarring in all sibs over the age of 4 years.

\section{Subjects}

The family study was based on a main group (I) comprising 198 consecutive index patients (84 boys and 114 girls) with VUR (without other malformation) and renal scarring admitted to The Hospital for Sick Children and the Shaftesbury Hospital for ureteric reimplantation between 1964 and 1976 inclusive, and a subsidiary group (II) of 8 patients ( 2 boys and 6 girls) attending the clinic in 1976 in whom there was VUR but no scarring. Of the main group of 198 families, 20 were not available for study because of migration (3), adoption (1), not traced (7), parental unwillingness to take part (6), family doctor advised against the study (3)-leaving 178 in group I and $186 \stackrel{2}{\circ}$ in all ( 81 boys and 105 girls).

\section{Methods}

FAMILY HISTORY

The parents and sibs of the index patients were seen (by AV and KE) either in their own homes or on 음 attending either hospital, with the exception of 2 living $\frac{D}{\vec{D}}$

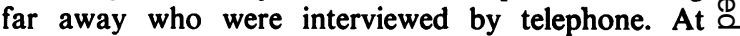
interview a family history was taken, paying special o attention to a history of hospital admissions for $\vec{\ominus}$ urinary tract infection (UTI) and especially VUR in sibs and parents.

\section{CLINICAL EXAMINATION}

The blood pressure of parents and sibs was recorded and the height and weight of the sibs. Mid-stream $\vec{G}$ specimens of urine (MSU) were collected from the first iv 126 of the parents and 103 of the sibs interviewed, but or were then discontinued as confirmed positive cultures were obtained in only 2 of the parents and in none of the sibs. Relatives were further investigated if they had $\rightarrow$ a documented history of recurrent UTI, and raised blood pressure, or had previously had uroradiological $\overrightarrow{\vec{\varphi}}$ investigations (these are henceforward called 'symptomatic').

\section{RADIOLOGICAL INVESTIGATION}

The results of investigations were classified simply as showing (a) the presence or absence of VUR on MCU and (b) the presence or absence of renal scarring on IVU. Those relatives with scarring, but with no demonstrable VUR, were classified as probably affected if they had had proven UTI in childhood, and as possibly affected if they had no such history in childhood.

\section{Results}

The families are listed in Appendix I, which shows, for index patients, degrees of reflux (grading as in Smellie, 1967, and Rolleston et al., 1975) and of renal damage (basically as classified by Smellie et al., 1975; Rolleston et al., 1970). It also gives information about those sibs and parents selected for routine investigation; those selected for investigation because they $N$ were 'symptomatic'; the investigation performed; whether VUR was demonstrated; and whether scarring 0 was found. Appendix II gives details of the condition $\omega$ in each affected relative.

\section{TWINS}

Two index patients, 1 of each sex (Nos. 104 and 185) were members of a monozygotic twin pair. The male $\frac{T}{T}$ co-twin had bilateral VUR with left scarring; the $\frac{\vec{D}}{\mathbb{D}}$ female co-twin was found unaffected on investigation $\frac{?}{8}$ by $M C U$. 
Table 1 Sibs aged less than 4 years in all 186 families; results of $M C U$

\begin{tabular}{|c|c|c|c|c|c|c|c|c|c|}
\hline \multirow{2}{*}{$\begin{array}{l}\text { Index } \\
\text { Patient }\end{array}$} & \multicolumn{3}{|l|}{ Brothers } & \multicolumn{3}{|l|}{ Sisters } & \multicolumn{3}{|c|}{ All sibs } \\
\hline & Number & $\begin{array}{l}\text { MCU } \\
\text { performed }\end{array}$ & $V U R$ & Number & $\begin{array}{l}\text { MCU } \\
\text { performed }\end{array}$ & $\overline{V U R}$ & $\begin{array}{l}\text { Total } \\
\text { sibs }\end{array}$ & $\begin{array}{l}M C U \\
\text { performed }\end{array}$ & $V U R$ \\
\hline $\begin{array}{l}\text { Male } \\
\text { Female }\end{array}$ & $\begin{array}{r}8 \\
14\end{array}$ & $\begin{array}{l}5 \\
6\end{array}$ & $\begin{array}{l}1 \\
0\end{array}$ & $\begin{array}{l}9 \\
8\end{array}$ & $\begin{array}{l}6 \\
3\end{array}$ & $\begin{array}{l}2 \\
0\end{array}$ & $\begin{array}{l}17 \\
22\end{array}$ & $\begin{array}{r}11 \\
9\end{array}$ & $\begin{array}{l}3 \\
0\end{array}$ \\
\hline Total & 22 & 11 & 1 & 17 & 9 & 2 & 39 & 20 & 3 \\
\hline
\end{tabular}

Four index patients, 2 of each sex, were members of dizygotic pairs. One male index patient (No. 33) had a girl co-twin who had ureteric dilatation on IVU, probably caused by earlier VUR, but was not investigated by MCU: the other male index patient (No. 41) had a twin brother who was 'asymptomatic' and his parents did not wish for investigation. One female index patient (No. 127) had a girl co-twin who was normal on investigation, the other (No. 167) had a girl co-twin who was 'asymptomatic' but whose parents did not wish for investigation.

In summary, 1 of 2 monozygotic co-twins was affected with reflux and scarring, 1 of 4 dizygotic cotwins had dilatation of the upper urinary tract probably resulting from VUR, but 2 of the remaining 3 were not investigated radiologically.

\section{S I B S}

(a) Sibs under 4 years in total 186 families (Table 1) There were 39 sibs in this group and the parents agreed to an MCU being performed in 20 of them (11 boys and 9 girls).

One brother of a boy patient (No. 36) was found to have bilateral VUR and scarring of the left kidney, 1 sister of a boy patient (No. 40) was found to have left reflux with scarring, and 1 sister (No. 179) was found to have right VUR without scarring. These 3 children were 'asymptomatic'. In addition 1 brother of a girl patient (No. 84) had left megaureter without VUR.

In sum, of 11 brothers routinely tested (out of a total of 22), 1 was found to have VUR, and of 9 sisters tested (out of a total of 17), 2 were found to have VUR. There was also 1 sister with symptoms of UTI who was not investigated by MCU. (b) Sibs aged over 4 years in first 29 families (Table 2) Again, there were 39 sibs in the group and IVUs were performed on 26 of them ( 13 boys and 13 girls).

In none of these was scarring found on IVU. However, 2 'asymptomatic' sisters of male index patients (Nos. 110 and 181) aged 4 and 5 years were examined by MCU (contrary to the procedure of the investigation) and found in the first case to have right VUR (no IVU was done) and in the second to have bilateral VUR without scarring.

In sum, none of 13 brothers examined (out of a total of 20) was found to have reflux, but 2 of 15 sisters examined by MCU (out of a total of 19) had reflux.

\section{(c) Sibs aged over 4 years in remaining 157 families (Table 3)}

There were 214 sibs in the group. Two teenage sisters of girl patients were already known to have had symptoms in childhood and been investigated radiographically. One (No. 180) had right VUR with a scarred duplex right kidney; 1 (No. 125) had bilateral scarring with renal failure (she was on regular haemodialysis) but had not been shown to have VUR. A further 7 brothers and 10 sisters were 'symptomatic' and parents agreed to IVP in all 7 brothers and 8 of the sisters. Of these, 2 brothers of girl patients (Nos. 115 and 172) were found to have bilateral VUR with bilateral scarring and bilateral VUR with left scarring, respectively; 3 sisters of girl patients (Nos. 122, 162, and 135) had, respectively, right VUR, right VUR, and right scarring without demonstrable VUR. Another 2 sisters (Nos. 41 and 173) had a history of repeated UTI with bacteriuria, but their parents did not wish for investigation.

In sum, 2 of 7 brothers with symptoms (out of a total of 104 brothers) and 3 of 12 sisters with

Table 2 Sibs aged more than 4 years in first 29 families; results of IVU and MCU*

\begin{tabular}{|c|c|c|c|c|c|c|c|c|c|c|c|c|c|}
\hline \multirow{2}{*}{$\begin{array}{l}\text { Index } \\
\text { patients }\end{array}$} & \multicolumn{3}{|l|}{ Brothers } & \multicolumn{5}{|l|}{ Sisters } & \multicolumn{5}{|l|}{ All sibs } \\
\hline & Number & $\begin{array}{l}\text { IVU } \\
\text { performed }\end{array}$ & $\begin{array}{l}\text { Renal } \\
\text { Scars }\end{array}$ & Number & $\begin{array}{l}\text { IVU } \\
\text { performed }\end{array}$ & $\begin{array}{l}\text { Renal } \\
\text { Scars }\end{array}$ & $\begin{array}{l}\text { MCU } \\
\text { performed }\end{array}$ & $\overline{V U R}$ & Number & $\begin{array}{l}\text { IVU } \\
\text { performed }\end{array}$ & $\begin{array}{l}\text { Renal } \\
\text { Scars }\end{array}$ & $\begin{array}{l}\text { MCU } \\
\text { performed }\end{array}$ & $V U R$ \\
\hline $\begin{array}{l}\text { Male } \\
\text { Female }\end{array}$ & $\begin{array}{r}7 \\
13\end{array}$ & $\begin{array}{l}5 \\
8\end{array}$ & $\begin{array}{l}0 \\
0\end{array}$ & $\begin{array}{r}10 \\
9\end{array}$ & $\begin{array}{l}7 \\
6\end{array}$ & $\begin{array}{l}\mathbf{0} \\
\mathbf{0}\end{array}$ & $\begin{array}{l}2 \\
0\end{array}$ & $\begin{array}{l}2 \\
0\end{array}$ & $\begin{array}{l}17 \\
22\end{array}$ & $\begin{array}{l}12 \\
14\end{array}$ & $\begin{array}{l}0 \\
0\end{array}$ & $\begin{array}{l}2 \\
0\end{array}$ & $\begin{array}{l}2 \\
0\end{array}$ \\
\hline Total & 20 & 13 & 0 & 19 & 13 & 0 & 2 & 2 & 39 & 26 & 0 & 2 & 2 \\
\hline
\end{tabular}

*MCU performed contrary to procedure. 
Table 3 Sibs aged more than 4 years in remaining 157 families; results of IVU and MCU* in symptomatic cases

\begin{tabular}{|c|c|c|c|c|c|c|c|c|c|c|c|c|c|c|c|}
\hline \multirow{3}{*}{$\begin{array}{l}\text { Index } \\
\text { patient }\end{array}$} & \multicolumn{5}{|l|}{ Brothers } & \multicolumn{5}{|l|}{ Sisters } & \multicolumn{5}{|c|}{ All sibs } \\
\hline & \multirow[t]{2}{*}{ Number } & \multirow{2}{*}{$\begin{array}{l}\text { Sympto- } \\
\text { matic }\end{array}$} & \multirow{2}{*}{$\begin{array}{l}\text { IVU } \\
\text { per- } \\
\text { formed }\end{array}$} & \multicolumn{2}{|c|}{ Renal scars } & \multirow[t]{2}{*}{ Number } & \multirow{2}{*}{$\begin{array}{l}\text { Sympto- } \\
\text { matic }\end{array}$} & \multirow{2}{*}{$\begin{array}{l}I V U \\
\text { per- } \\
\text { formed }\end{array}$} & \multicolumn{2}{|c|}{ Renal scars } & \multirow[t]{2}{*}{ Total } & \multirow{2}{*}{$\begin{array}{l}\text { Sympto- } \\
\text { matic }\end{array}$} & \multirow{2}{*}{$\begin{array}{l}I V U \\
\text { per- } \\
\text { formed }\end{array}$} & \multicolumn{2}{|c|}{ Renal scars } \\
\hline & & & & $V U R+$ & $V U R-$ & & & & $V U R+$ & $V U R-$ & & & & $V U R+$ & $V U R-$ \\
\hline Male & 38 & 2 & 2 & 0 & 0 & 42 & 3 & 2 & 0 & 0 & 80 & 5 & 4 & 0 & 0 \\
\hline Female & 66 & 5 & 5 & 2 & 0 & 68 & 9 & 8 & 3 & 2 & 134 & 14 & 13 & 5 & 2 \\
\hline Total & 104 & 7 & 7 & 2 & 0 & 110 & 12 & 10 & 3 & 2 & 214 & 19 & 17 & 5 & 2 \\
\hline
\end{tabular}

*MCU was only done if IVU showed renal scarring.

symptoms (out of a total of 110 sisters) had reflux; 2 further sisters among these 12 had scarring probably associated with earlier reflux, of whom 1 was on haemodialysis.

\section{PARENTS}

Only 2 parents (father of 116 and mother of 161 ) were identified as having renal scarring as a result of the survey, but several had had symptoms and had already been investigated radiologically.

One father of a boy patient (No. 99) had a history of chronic UTI in childhood, had been found at the age of 12 to have bilateral dilatation of the ureters and hydronephrosis, and at 19 had had an operation to relieve 'bladder neck obstruction'; 1 father of a girl patient (No. 126) with symptoms from childhood had had reimplantation of the left ureter at age 19 for dilatation of the left ureter with renal scarring; 1 father of a girl (No. 116) in the course of the survey was found to have hypertension and UTI and to have right renal scarring; 2 fathers investigated because of symptoms were found unaffected. One mother of a boy patient (No. 179) was known to have a right duplex kidney and ureter with VUR and scarring; 1 mother of a girl patient (No. 70) was known to have bilateral renal scarring and was on regular haemodialysis; 1 mother of a girl (No. 161) was found in the course of the survey to have hypertension, UTI, rightsided dilatation of the ureter, and renal scarring; 1 mother of a girl (No. 180) was known to have had bilateral VUR and renal scarring and had had reimplantation of both ureters at the age of 19 years; 1 mother of a girl (No. 184) was known to have had bilateral VUR and scarring and had had reimplan- tation of both ureters at age $8 ; 1$ mother of a girl (No. $\vec{\circ}$ 144) was known to have had dilatation of the right $\overrightarrow{\vec{\omega}}$ upper urinary tract with scarring but without $\stackrel{\sigma}{\omega}$ symptoms in childhood; 1 mother of a girl (No. 165) was known to have left renal scarring, found on investigation at age 18 , but without childhood $\vec{r}$ symptoms.

In sum, 3 fathers of the 181 on whom information of was available had scarring, in 2 probably and in 1 은 possibly secondary to VUR; of 183 mothers on whom information was available 3 had demonstrated $D$ VUR and scarring, 1 scarring probably secondary to VUR, and 3 scarring possibly secondary to VUR.

\section{OTHER RELATIVES}

\section{Aunts and uncles}

The patients had 279 fathers' brothers and 216 fathers' sisters, and 233 mothers' brothers and $246 \stackrel{\circ}{\circ}$ mothers' sisters. No investigations on these were $\varnothing$ carried out, but on taking the family history, and $\overrightarrow{\overrightarrow{0}}$ obtaining confirmation from hospital records, it was 3 found that: 1 mother's brother (No. 2) with Down's syndrome died aged 22 months of bilateral pyelonephritis, and 1 mother's sister (No. 24) had dilatation of the upper urinary tract probably caused by VUR; 10 mothers' sister (No. 89) had scarring with proven $\frac{5}{3}$ VUR and 1 mother's sister (No. 146) had dilatation of both ureters and right scarring.

\section{Cousins}

The patients' cousins included: 207 fathers' brothers' sons and 186 daughters; 206 fathers' sisters' sons and 192 daughters; 166 mothers' brothers' sons and 192 N

Table 4 Parents: results of IVU (mostly performed before the survey) in those symptomatic

\begin{tabular}{|c|c|c|c|c|c|c|c|c|c|c|c|c|c|}
\hline \multirow{3}{*}{$\begin{array}{l}\text { Index } \\
\text { patients }\end{array}$} & \multicolumn{4}{|l|}{ Fathers } & \multicolumn{4}{|l|}{ Mothers } & \multicolumn{5}{|l|}{ All parents } \\
\hline & \multirow{2}{*}{$\begin{array}{l}\text { Number } \\
\text { available }\end{array}$} & \multirow{2}{*}{$\begin{array}{l}\text { Sympto- } \\
\text { matic }\end{array}$} & \multirow{2}{*}{$\begin{array}{l}\text { IVU } \\
\text { per- } \\
\text { formed }\end{array}$} & \multirow{2}{*}{$\begin{array}{l}\text { Renal } \\
\text { scars }\end{array}$} & \multirow{2}{*}{$\begin{array}{l}\text { Number } \\
\text { available }\end{array}$} & \multirow{2}{*}{$\begin{array}{l}\text { Sympto- } \\
\text { matic }\end{array}$} & \multirow{2}{*}{$\begin{array}{l}I V U \\
\text { per- } \\
\text { formed }\end{array}$} & \multirow{2}{*}{$\begin{array}{l}\text { Renal } \\
\text { scars }\end{array}$} & \multirow{2}{*}{$\begin{array}{l}\text { Total } \\
\text { available }\end{array}$} & \multirow{2}{*}{$\begin{array}{l}\text { Sympto- } \\
\text { matic }\end{array}$} & \multirow{2}{*}{$\begin{array}{l}\text { IVU } \\
\text { per- } \\
\text { formed }\end{array}$} & \multicolumn{2}{|c|}{ Renal scars } \\
\hline & & & & & & & & & & & & $V U R+$ & $V U R-$ \\
\hline $\begin{array}{l}\text { Male } \\
\text { Female }\end{array}$ & $\begin{array}{r}78 \\
103\end{array}$ & $\begin{array}{l}3 \\
4\end{array}$ & $\begin{array}{l}1 \\
4\end{array}$ & $\begin{array}{l}1 \\
2\end{array}$ & $\begin{array}{r}79 \\
104\end{array}$ & $\begin{array}{l}19 \\
19\end{array}$ & $\begin{array}{l}15 \\
15\end{array}$ & $\begin{array}{l}1 \\
6\end{array}$ & $\begin{array}{l}157 \\
207\end{array}$ & $\begin{array}{l}22 \\
23\end{array}$ & $\begin{array}{l}16 \\
19\end{array}$ & $\begin{array}{l}0 \\
3\end{array}$ & $\begin{array}{l}2 \\
5\end{array}$ \\
\hline Total & $181^{*}$ & 7 & 54 & 3 & $183^{*}$ & 38 & 30 & 7 & 364 & 45 & 35 & 3 & 7 \\
\hline
\end{tabular}

* 5 fathers and 3 mothers were not available for study. 
daughters; 224 mothers' sisters' sons and 240 daughters. Again on taking the family history and obtaining confirmation from hospital records it was found that 1 father's brother's daughter (No. 76) had confirmed bilateral VUR with left scarring; 1 father's sister's daughter (No. 156) had bilateral VUR with bilateral scarring; 1 mother's brother's daughter (No. 83) had right VUR with bilateral bifid renal pelvis; and 1 mother's sister's son (No. 146) had bilateral VUR with no scarring.

\section{Discussion}

The two groups, those with, and a small group of 8 without, renal damage, may be considered together since the family findings do not differ, and they have been grouped together in the Tables. The 8 families are, however, shown separately in the Appendix.

The significance of findings in relatives depends on the frequency with which individuals similarly affected would be found in the general population. A number of small scale studies have been carried out in which routine micturating cystograms were performed on a series of children without evidence of urinary tract infection. These have shown a fairly low prevalence of VUR. For example Peters et al. (1967) found no VUR in 66 premature infants, Lich et al. (1964) found no cases in 24 children in the neonatal period, Jones and Headstream (1958) found 1 case (in a 4-month-old boy) in 70 boys and 30 girls aged 14 days to 14 years (mean age 3.5 years) in children who had a 'nonurological admission with a negative urinalysis'. These small series indicate that perhaps about $1 \%$ of a randomly selected group of young children would be found to have VUR on MCU.

In contrast in the sibs under 4 in this series, offered routine MCU, the observed proportion with VUR lay between 1 in 11 brothers and 2 in 9 sisters (if it is assumed that those tested were representative of the whole group) and 1 in 22 for brothers and 2 in 17 for sisters (assuming none of the 15 sibs not tested have reflux).

None of the 26 sibs (out of a total of 39) over the age of 4 years in the 29 families where the parents were offered routine investigation by IVU was found to have had scarring. It is noteworthy, however, that the two symptomless sisters, who contrary to procedure had a direct MCU, were found to have reflux.

A less direct approach to the prevalence of reflux in children is given by studies of series of children for significant bacteriuria followed by micturating cystograms of those found positive. A number of such studies on schoolgirls suggest (Meadow et al., 1969; Asscher et al., 1973; Savage et al., 1973; Parson et al., 1974) that some $2 \%$ of girls between the ages of 5 and 10 have significant bacteriuria and that where these are examined by micturating cystogram about a quarter of them have reflux. By this method the prevalence of reflux in schoolgirls is about $0.5 \%$. However, these studies will miss those with reflux without infection and reflux which was present in early childhood but has ceased.

Unfortunately there is no routine series, in which after a full medical history, children and adults who have had repeated urinary tract infection have been investigated, with which to compare directly the findings in sibs over 4 years of age, and in the parents. However, if one assumes that about $1 \%$ of young children have reflux, that in about half the girls and less than half of the boys this leads to recurrent urinary tract infection, and that in half again this leads to renal scarring, one might expect about $0.25 \%$ of girls and somewhat fewer boys, perhaps $0.15 \%$, to have renal scarring in association with reflux and recurrent urinary tract infection.

In contrast in the main group of families (Table 3) where the parents were not offered routine investigation of sibs over 4 years of age, 2 brothers out of 104 were shown to have reflux, 3 sisters out of 110 to have reflux, and 2 further sisters had scarring probably secondary to reflux (one of them was on regular haemodialysis). This again suggests that the proportion of brothers and sisters affected is more than 10 times that in the general population. Similarly it is noteworthy (see Table 4) that of 181 fathers, 2 were found to have scarring probably caused by reflux and 1 had scarring possibly caúsed by reflux, while of 183 mothers 3 had reflux, 1 had scarring probably secondary to reflux (and was on renal haemodialysis), and 3 had scarring possibly secondary to reflux. This again is some $\mathbf{1 0}$ times the expected proportion for men and women, respectively.

The ascertainment of affected aunts and uncles will inevitably be incomplete. For example, the index patient's mother may not know details of the health of her husband's brothers' children. It is also often difficult to get confirmation from hospital records of such more distant relatives. In view of these limitations the finding of 1 in 502 uncles and 3 in 462 aunts, 1 of 390 male and 3 of 393 female cousins affected probably represents a real though small increase over the expected values.

\section{GENETIC MECHANISM S}

The genetic interpretation of the familial concentrations found in this survey must be cautious, particularly in view of the approximate estimate of the incidence of reflux in the general population. The findings, however, are in general similar to those for other common congenital malformations such as cleft lip ( \pm cleft palate), pyloric stenosis, talipes equinovarus, and pyloric stenosis (Carter, 1976). They 
are most economically interpreted as reflecting a multifactorial aetiology of the malformation, with the genetic predisposition depending on variation at several gene loci. This type of inheritance has already been suggested by Burger and Smith (1971). A birth frequency of the malformation of $1 \%$, and a heritability of the malformation of $90 \%$, would give on the multifactorial model $10 \%, 3 \%$, and $2 \%$ affected, respectively, of first, second, and third degree relatives. The findings in this survey are compatible with these figures, but these do not exclude other mechanisms such as modified dominant inheritance.

The relatively high risk to the younger sibs of index patients suggests that these could be an appropriate group in whom to assess the value of early diagnosis and prophylactic treatment in the prevention of reflux nephropathy.

We are grateful to the staff of the Departments of Radiology and Chemical Pathology in both hospitals. We also thank the nursing staff at the Shaftesbury Hospital for their co-operation and Mrs Joan Warren and Dr T. Mazurczak who helped with visiting the families.

\section{References}

Amar, A. D. (1972). Familial vesico-ureteral reflux. Journal of Urology, 108, 969-971.

Atwell, J. D., Cook, P. L., Strong, L., and Hyde, I. (1977). The inter-relationship between vesico-ureteric reflux, trigonal abnormalities and a bifid pelvicalyceal collecting system; a family study. British Journal of Urology, 49, 97-107.

Asscher, A. W., McLachlan, M. S. F., Jones, R. V., Meller, S., Sussman, M., Harrison, S., Johnston, H. H., Sleight, G., and Fletcher, E. W. (1973). Screening for asymptomatic urinary tract infection in schoolgirls. Lancet, 2, 1-4.

Bailey, R. R. (1973). The relationship of vesico ureteric reflux to urinary tract infection and chronic pyleonephritis-reflux nephropathy. Clinical Nephrology, 1, 132-141.

Baker, R., Maxted, W., McCrystal, H., and Kelly, T. (1965). Unpredictable results associated with treatment of 133 children with uretero-renal reflux. Journal of Urology, 94, 362-375.

Bois, E., Feingold, J., Benmaiz, H., and Briard, M. L. (1975). Congenital urinary tract malformations: epidemiologic and genetic aspects. Clinical Genetics, 8, 37-47.

Burger, R. H., and Smith, C. (1971). Hereditary and familial vesicoureteral reflux. Journal of Urology, 106, 845-851.

Carter, C. O. (1976). Genetics of common single malformations. British Medical Bulletin, 32, 21-26.

Dwoskin, J. Y. (1976). Sibling uropathology. Journal of Urology, 115, 726-727.

Hodson, C. J., and Edwards, D. (1960). Chronic pyelonephritis and vesico-ureteral reflux. Clinical Radiology, 11, 219-231.
Jones, B. W., and Headstream, J. W. (1958). Vesico-ureteral reflux in children. Journal of Urology, 80, 114-115.

Lewy, P. R., and Belman, A. B. (1975). Familial occurrence of nonobstructive non-infectious vesico-ureteral reflux with renal scarring. Journal of Pediatrics, 86, 851-856.

Lich, R. Jr., Howerton, L. W., Jr., Goode, L. S., and Davis, L. A. (1964). The uretero-vesical junction of the newborn. Journal of Urology, 92, 436-438.

Meadow, S. R., White, R. H. R., and Johnston, N. M. (1969). Prevalence of symptomless urinary tract disease in Birmingham schoolchildren. I Pyuria and bacteriuria. British Medical Journal, 3, 81-84.

Mulcahy, J. J., Kelalis, P. P., Stickler, G. B., and Burke, E. C. ڤ (1970). Familial vesico-ureteral reflux. Journal of Urology, 104, 762-764.

Parsons, V., Patel, H. R., Stodell, A., Armstrong, P., Epsom, J. E., $\vec{\overrightarrow{ }}$ and Thrower, A. L. (1974). Symptoms by questionnaire and signs $\vec{\omega}$ by dipstream culture of urinary tract infection in schoolgirls of Southeast London. Clinical Nephrology, 2, 179-185.

Peters, P. C., Johnson, D. E., and Jackson, J. H. (1967). The incidence of vesico-ureteral reflux in the premature child. Journal $\vec{G}$ of Urology, 97, 259-260.

Rolleston, G. L., Shannon, F. T., and Utley, W. L. F. (1970). Relationship of infantile vesico-ureteric reflux to renal damage. $U$ British Medical Journal, 1, 460-463.

Rolleston, G. L., Shannon, F. T., and Utley, W. L. F. (1975). Follow-up of vesico-ureteric reflux in the newborn. Kidney International, 8, Suppl. 4, 59-64.

Savage, D. C. L., Wilson, M. I., McHardy, M., Dewar, D. A. E., and Fee, W. M. (1973). Covert bacteriuria of childhood. A clinical and epidemiological study. Archives of Diseases in Childhood, 48, 8-20.

Scott, J. E. S. (1977). The management of ureteric reflux. British Journal of Urology, 49, 109-118.

Scott, J. E. S., and Stansfeld, J. M. (1968). Ureteric reflux and kidney scarring in children. Archives of Disease in Childhood, 43, 468-470.

Smellie, J. M. (1967). Medical aspects of urinary infection in $\mathbb{D}$ children. Journal of the Royal College of Physicians of London, 1, 189-196.

Smellie, J. M., Edwards, D., Hunter, N., Normand, I. C. S., and Prescod, N. (1975). Vesico-ureteric reflux and renal scarring in urinary tract infection. Kidney International, 8, Suppl. 4, S65-72.

Smellie, J. M., and Normand, I. C. S. (1968). Experience of followup of children with urinary tract infection. In Urinary Tract Infaction, pp. 123-135. Ed. by F. O'Grady and W. Brumfitt. Oxford University Press, London.

Stephens, F. D., and Lenaghan, D. (1962). The anatomical basis and dynamics of vesico-ureteral reflux. Journal of Urology, 87, 669-680.

Tanagho, E. A., Guthrie, T. H., and Lyon, R. P. (1969). The intravesical ureter in primary reflux. Journal of Urology, 101, 824832.

Requests for reprints to Professor C. O. Carter, MRC Clinical Genetics Unit, Institute of Child Health, 30 Guilford Street, London WC1N 1EH. 


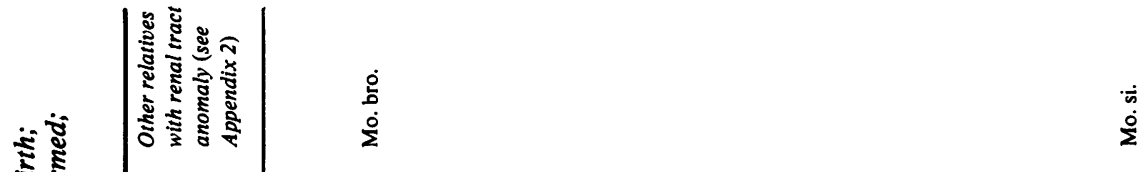

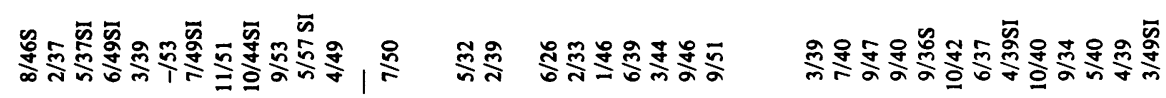

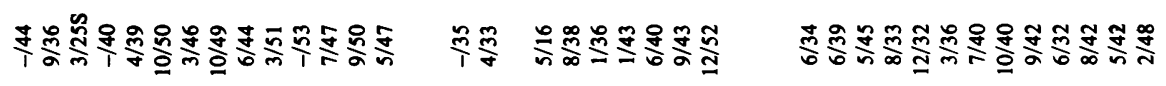

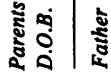

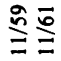

$\Sigma \Sigma$

$\stackrel{i}{\frac{1}{m}} \stackrel{\circ}{\frac{0}{n}}$

กํํ용

$\Xi$

I $\Sigma \Sigma$

$\Sigma \amalg \Sigma$

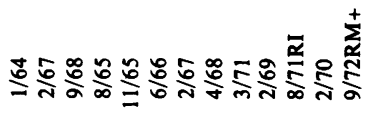

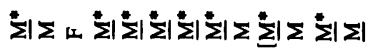

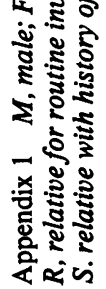

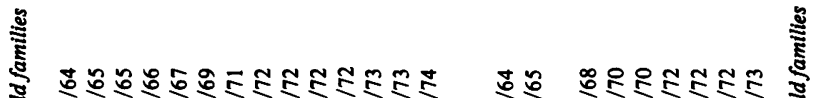

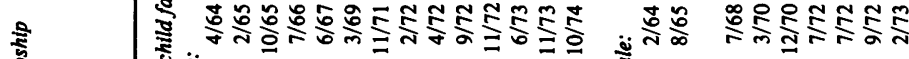

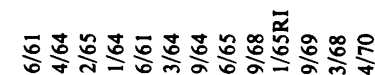




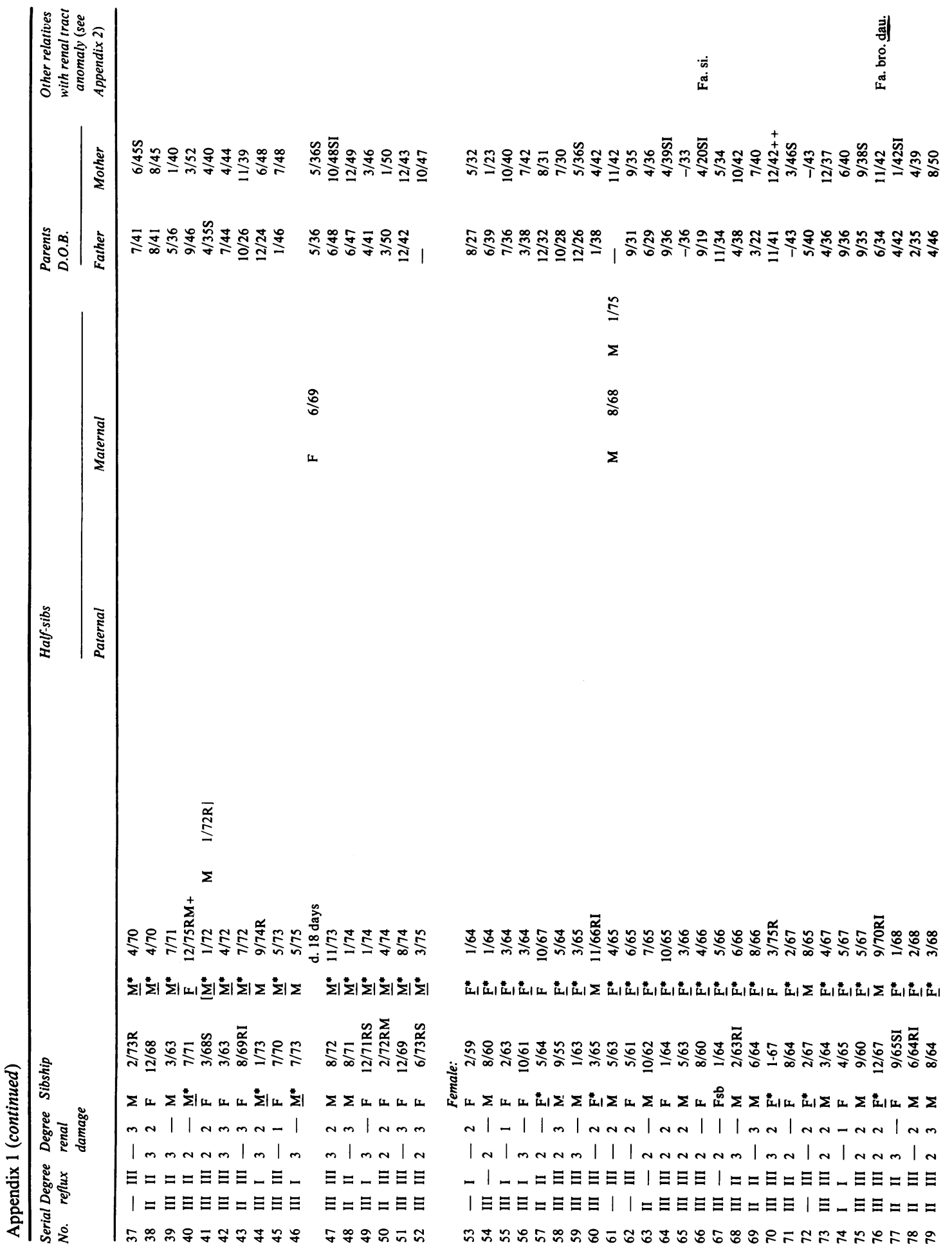




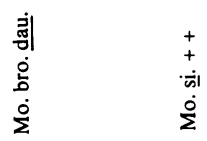

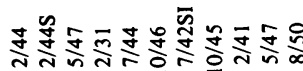

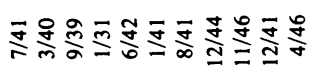

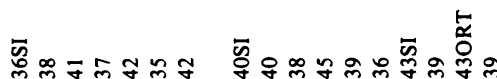

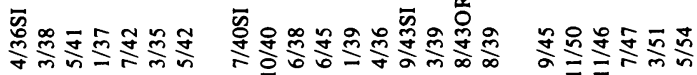

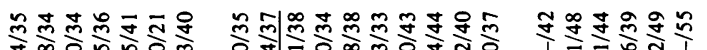

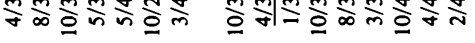

\author{
$\stackrel{\circ}{\check{2}}$
}

เ

$\frac{\infty}{8}$

乐

$\dot{\vec{\omega}}$
$\dot{\omega}$

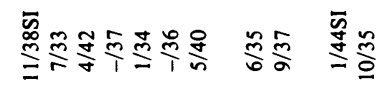

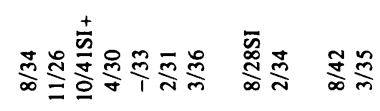

$$
\stackrel{\Xi}{\Sigma}
$$

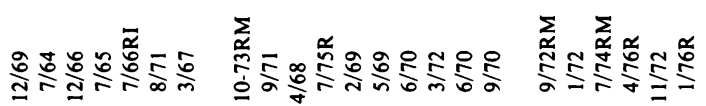

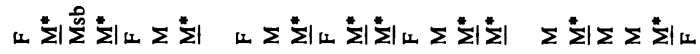

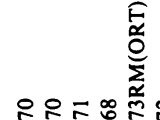

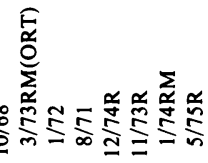

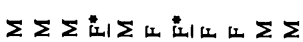

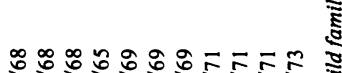

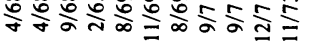

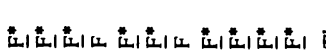
na $\mid$ n $\mid$ In $\mid \mathrm{mm}$ $m \operatorname{lm} \mid n \sim n n--m$

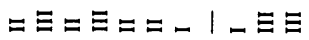
ニ|シーニニシーシーシ

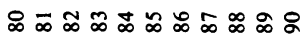

\section{है}

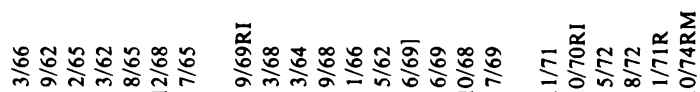

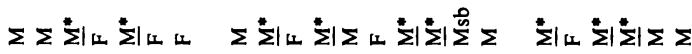

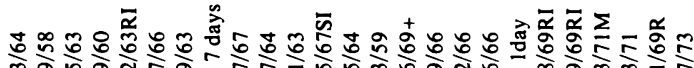
ฆัँ छั.

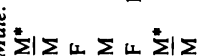

$$
-m-m n-1
$$

$\mid$ | $\mid$ Inm

ニ $\Xi \Xi \Xi \Xi \mid$

- | $\Xi \Xi \Xi \Xi \Xi$

$\sum \mid \Sigma \Sigma \Sigma \Sigma ⿻ 上 \Sigma ⿻ 上 丨$

$\sum \amalg\left|\Sigma \Sigma \sum\right|$

$n-|| \sim|1| \mid n$

amnan-nm

$\Xi_{-}-|=| \Xi_{-} \Xi$

| $\Xi \Xi \Xi \Xi \Xi$

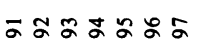

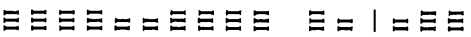

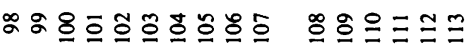

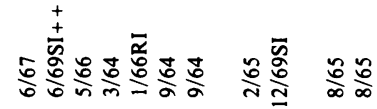

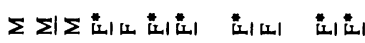

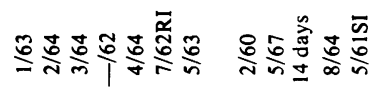

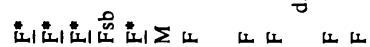

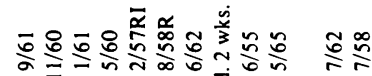

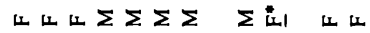
$\operatorname{lnm} \mid n \sim \operatorname{an~} m-$ mIInIIn ma ニニミーミミミミミミミ

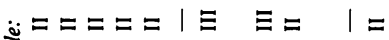

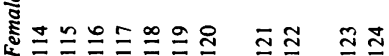




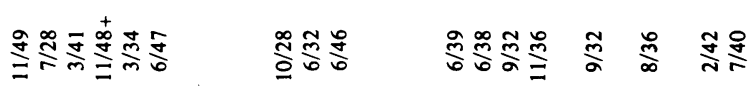

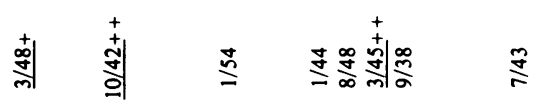

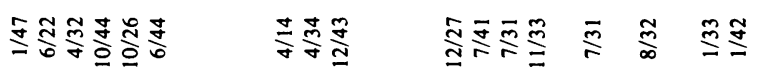

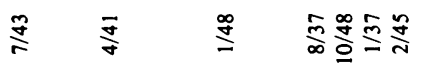

$\frac{\infty}{\infty}$

$\stackrel{3}{i}$

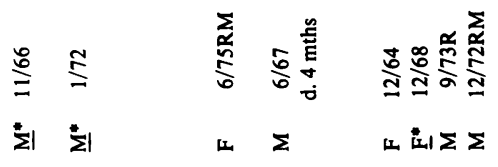

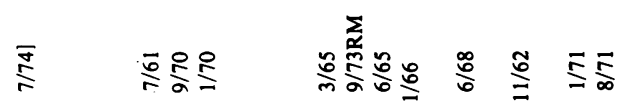

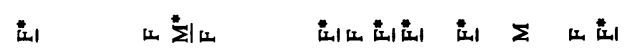

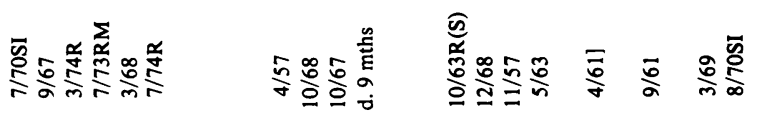

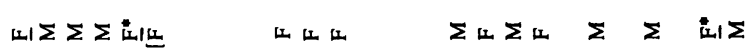

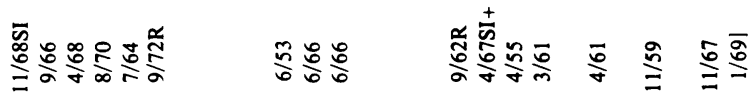

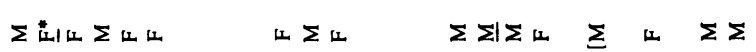

牙舟

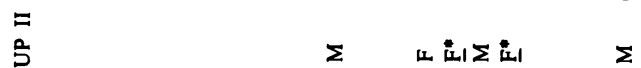

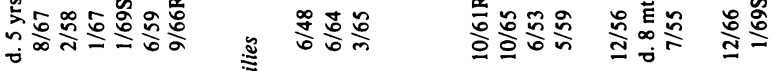

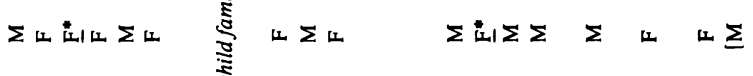

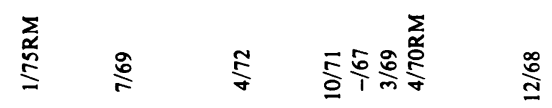

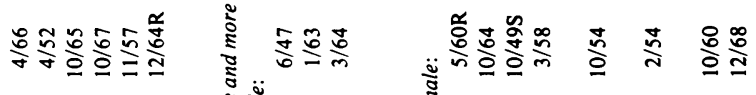

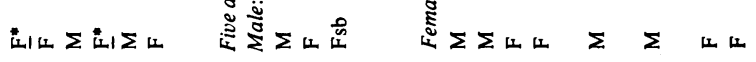

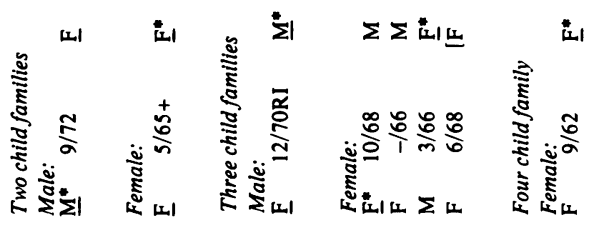
| I-nma n-m nan | nan $n|-| n \mid$ InI maml m n n

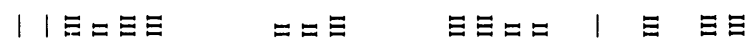

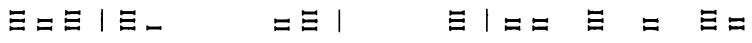

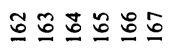
응요오 $\Xi \cong \cong \Xi \cong \cong ミ ゚$

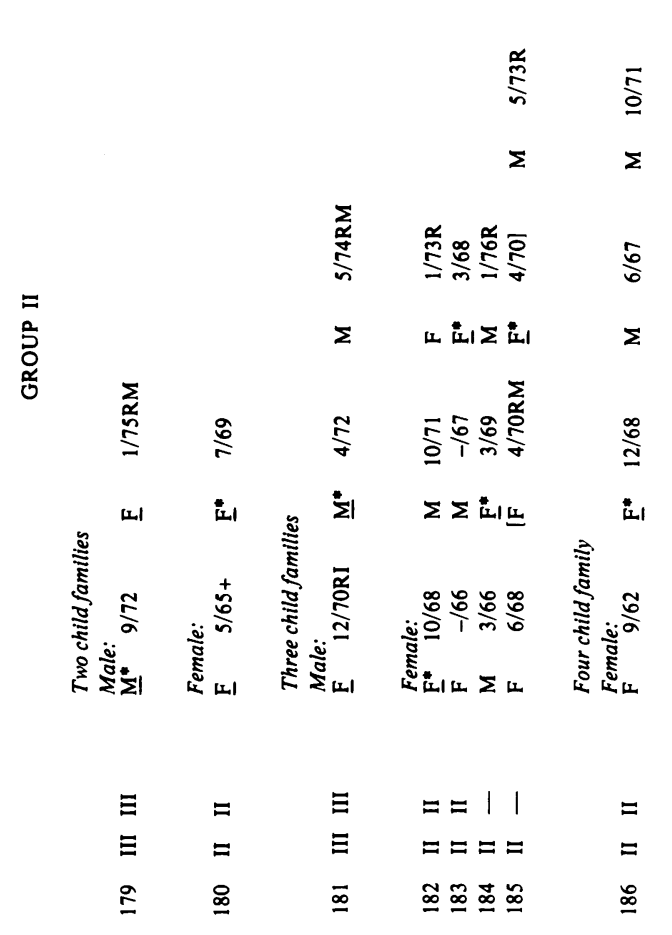


Appendix 2 Affected relatives including those with other renal tract anomaly (ORT)

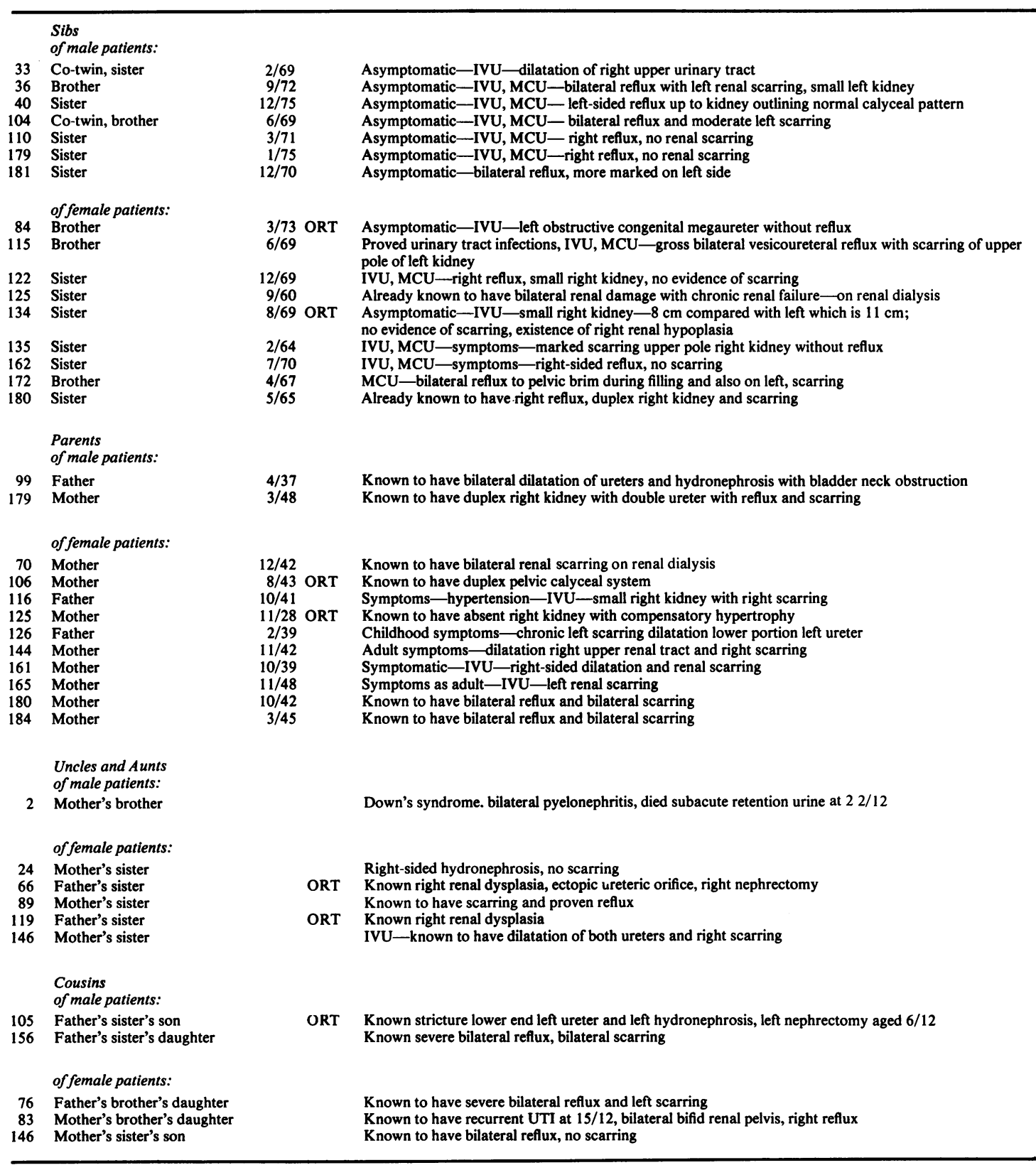

